\title{
Electoral Reform and Parliamentary Debates *
}

\author{
Bjørn Høyland and Martin G. Søyland \\ Department of Political Science \\ University of Oslo
}

*An earlier version of this paper was presented at the Challenges to Democracy conference at the University of Oslo in $5^{\text {th }}-6^{\text {th }}$ November 2015, at the Institutional Determinants of Legislative Coalition Management conference at the University of Tel Aviv $16^{\text {th }}-19^{\text {th }}$ November 2015 and at the Annual Norwegian Conference of Political Science at University of Agder, $6^{\text {th }}-8^{\text {th }}$ January 2016, at the Annual Meeting of the American Political Science Assoiciation $31^{\text {st }}$ August - $3^{\text {rd }}$ September 2017, and at a seminar at the Department of Political Science, University of Oslo. The authors would like to thank the participants for useful comments and suggestions, in particular Jon Fiva, Henning Finseraas, Orit Kedar, Sven-Oliver Proksch, Bjørn Erik Rasch, Kaare Strøm, Thomas Saalfeld, Jon Slapin and Daniel M Smith. Martin Søyland thanks the IQSS at Harvard University for their hospitality during the project. The authors gratefully acknowledge generous funding from the Research Council of Norway under the project The Evolution of Parliamentarism and Its Political Consequences, project number 222442. 


\begin{abstract}
The early $20^{\text {th }}$ century saw many democracies adopt proportional representative systems. The textbook explanation, pioneered by Rokkan (1970), emphasize between-party electoral competition; the rise of the Socialist vote-share made Bourgeois parties prefer PR systems to maximize their seat-share. While appealing, this account is not entirely compelling. Consequently, scholars are investigating withinparty explanations of support for such reforms. Particularly, Cox et al. (2019) show how list-PR enable party leaders to discipline members and build cohesive parties. Relying on roll call votes across the Norwegian 1919 electoral reform from two-round single member plurality to closed list PR, they show that that the internal party cohesion increased following the reform. We investigate how the Norwegian electoral reform changed the content of parliamentary speeches. Comparing speeches from MPs present both before and after the reform, we show how parties become more cohesive in parliamentary debates under list-PR than they were under the SMD-system.
\end{abstract}

Keywords: Electoral reform, parliamentary debates, text-as-data 
The early $20^{\text {th }}$ century saw many young democracies changing their electoral systems from single member plurality systems to proportional representative systems. The textbook explanation for this change, pioneered by Rokkan (1970) emphasize between-party electoral competition. In particular, the rise of the Socialist vote-share made fragmented Bourgeois parties prefer PR systems to minimize their seat-share loss in the aftermath of the introduction of universal suffrage. Boix (1999) provides a formalization and an empirical test of this argument (see also Boix, 2010). While the argument is elegant, it has been criticized on both empirical and conceptional grounds. Empirically, Blais et al. (2004) fail to find any systematic relationship between the "Socialist threat" and switching to proportional representation, while Leemann and Mares (2014), investigating district, rather than country level effects, indeed find that district level vulnerability and dead-vote disproportionality explain the adoption of PR. Calvo $(2009,256)$ argues that in countries such as Austria, Germany, Italy, the Netherlands and Norway, countries Rokkan (1970) use to argue the "Socialist threat", PR reforms were actually supported by the Social Democratic parties. Moreover, in those countries the reform improved the seat shares won by the Social Democratic parties rather than helping the old elite maximizing their seat shares. Moreover, the two-round election systems in place in many of these countries provided the divided bourgeois bloc able opportunity for between coordination after the first round (Blais et al., 2004; Calvo, 2009), although Fiva and Smith (2017a) point to geographical challenges to mobilizing and coordinating the party vote the local candidate redraws. Nevertheless, Fiva and Hix (2018) demonstrate that within group voter coordination fell in Norway in the aftermath of the reform to PR.

The reduced incentive to cater for voter coordination in PR system has implications for within-party dynamics. As a result, legislative scholars have started to investigate withinparty effects of electoral systems more general, and the effects of electoral reforms on legislative behavior in particular (for an overview of this literature, see Andre et al., 2014). When studying the effect of electoral systems on legislative behavior, a key distinction is made between candidate- and party- centered systems (Hix, 2002; Hix, 2004; Carey, 2007). In the former system, voters can choose their most preferred candidates, while in 
the latter, voters are only provided a meaningful choice between parties. In candidate centered systems legislators vote less in line with the party (Carey, 2007; Depauw and Martin, 2009; Cox et al., 2019), focus more on their constituencies (McLay and Vowles, 2007; Høyland et al., 2017), and run more personal campaigns (Catalinac, 2016, 2017). Such behavior is mainly attributed to individual candidates' incentive to influence their electoral prospects independently of the party leadership. Of particular relevance to us, Cox et al. (2019) investigate how list-PR grants party leaders control of the nomination process which in turn enable them to discipline their members and build cohesive parties. Relying on roll call votes before and after the Norwegian 1919 electoral reform from tworound single member plurality to closed list PR, they show that party leaders preferred the reform to a larger degree than rank-and-file members, and that the internal party cohesion increased following the reform.

We propose that electoral rules are also reflected in the topics that legislators chose to emphasize during the debates. Building on Cox et al. (2019), we investigate how this reform changed content of parliamentary speeches in the Norwegian Parliament. Comparing parliamentary speeches of MPs present both before and after the reform, we demonstrate that the reform shifted the focus of speeches from individual MPs to parties. In short, we claim that the reform to list-PR, in addition to make the parties more cohesive in votes, also made them more cohesive in parliamentary debates.

\section{Electoral Rules, Reforms, and Legislative Behavior}

Electoral rules shape legislative behavior by generating varying degree of incentives for cultivate a personal vote relative to promoting a clear and consistent party message. The centralized nomination procedure in a closed list system incentivizes legislators to toe the party line while a decentralized candidate selection procedure in small electoral districts incentives legislators to cultivate personal ties to enhance their own profile even at the expense of the unity of the party message. Indeed, in the latter system "Maverick" MPs may develop a name for themselves independently of the party they happen to represent 
(Martin, 2011). As a result, legislators from candidate-centered systems spend more time on activities that increase their visibility with votes than legislators from party-centered systems (Obholzer and Daniel, 2016). Career-minded legislators from party-centered systems spend more time on legislative activities than similar legislators from candidatecentered systems, in particular when such activities offer few possibilities for personal credit visibility (Høyland et al., 2017). While these differences across electoral systems are well known (Andre et al., 2014), it is difficult to establish whether they are due to different types seeking legislative careers under different electoral rules, or because the electoral rules alter how legislators of similar type behave. In order to isolate the later effect from the former, a promising avenue it to look how legislators alter their behavior following an electoral reform.

Research on the effect of electoral reform on legislative behavior has found that changing from candidate-centered to party-centered electoral systems reduce the level of constituency work (McLeay and Vowles, 2007). Katz and Sala (1996), studying the introduction of the Australian ballot in the US, find that this shift towards a more candidatecentered system made legislators less likely to change committees, while Wittrock et al. (2008) find that legislators became less loyal to their party following the reform. Carson and Sievert $(2015,90)$ revisit this reform, but improve the research design by adopting a cross-over design, i.e. "a sequential comparison of units who change between treatment and control" (see also Imai et al., 2011, 782). While they fail to find support for any effect of the reform on committee assignments, they do find that legislators that participated in more than 65 per cent of the votes became less loyal to the party line after the reform. Adopting a similar research design to study the Norwegian 1919 electoral reform, which strengthen the parties, Cox et al. (2019) do indeed find higher degree of party unity following the reform. In contrast, Coman (2012), studying the 2008 reform from proportional representation to single member districts in Romania, finds that MPs became more likely to defect in less important votes only.

Because of the binary nature of votes, scholars has recently started to explore how legislators may use debates to distinguish their views from the party line and enhance 
their name recognition (Slapin and Proksch, 2014). Although legislative debates offer more opportunities for expressing views that may differ from the party line, Proksch and Slapin (2012) argue the institutional rules still structure parliamentary debates. Agendacontrol and rules for allocating speech rights means that access to the floor, and the ability to express dissent from the position of the party leadership varies. Comparing debates in the British House of Commons and the German Bundestag, Proksch and Slapin (2015) argue that it is more accepted and better opportunities for expressing dissent in the former than in the latter. Further, Bäck and Debus (2016) show how some MPs take the floor more often than others and when they deviate from the party line, over several political systems (including Norway, Sweden, Czech Republic, and more). Herzog and Benoit (2015), utilizing parliamentary debates, found that party and office were important for position taking by Irish MPs in the aftermath of the 2008 financial crisis. However, they also find that constituency interests affected MP behavior in parliament for MPs from the constituencies that were hit the hardest.

Spirling (2016) shows that the extension of the franchise in Victorian England led party leaders to reduce the linguistic complexity in their speeches to a greater extent than back-benchers. This, he argues, was in order to put their party-view across to a growing and less literate electorate. Moreover, investigating the effect of an electoral reform in New Zealand, Proksch and Slapin (2015, 163-173) find that more party rebels were granted floor under the more candidate-centric set of electoral rules.

While these studies have shown differences in floor access and the complexity of language used depending on the electoral rules, the literature remains silent on the effect of electoral reform on the content of parliamentary debates. We propose that electoral rules are also reflected in the topics that legislators chose to emphasize during the debates. In particular, we expect more debates with focus on individual legislators under candidate-centered electoral systems, and debates with focus on party differences under party-centered systems. In other words, as the reform altered the Norwegian electoral system from candidate-centric to party-centric, we expect the composition of topics to change accordingly. 


\section{Electoral reform in Norway}

The first part of the $20^{t h}$ century was a period of big reforms and change for the newly independent Norwegian state. Building a system for education, expanding infrastructure (especially by rail), and establishing tariffs for the primary industry (agriculture and fish trade) were some of the important tasks that dominated the agenda in the legislature during the start of the 20th century. For example, from the start of the 20th century to 1925, almost 2000 kilometers of railway tracks were put down across the country, production in the agricultural and fish sectors increased, and the gross national product almost doubled from 1920 to 1940 (Furre, 2000, 21). Moreover, World War I had a major impact the economy. Struggling to maintain neutrality, Norway aimed to balance German demands for fish import against British demands not to trade with their enemy (Furre, 2000, 24). High inflation eventually lead to rationing in 1918. The next decade was characterized by a struggle to reduce the national debt, and improve the economy (Furre, 2000, 28). Consequently, tax and toll rates rose formidably in the 1920s, in attempts to limit the debt burden. Further, the Russian revolution in 1917 had a great impact on the strategy of the Labor Party; in order to keep the masses from being oppressed, the party demanded the right to employ a revolutionary mass action (Furre, 2000, 36). These developments are of course reflected in parliamentary debates of the time. Military structure, budget cuts, toll rates, and the contestation between the establishment and the socialist movement are prevalent topics throughout the period.

In sum, factors that could have changing effects on the content and form of parliamentary debates are plentiful. However, our main interest and argument is the effect of the electoral reform passed in 1919 - changing the election system from plurality vote in single member districts to proportional representation (Haffner, 1949, 69) - on parliamentary debate.

Transitions to PR are often explained by the rising threat of labor parties, which incentivized bourgeois parties to change the electoral formula in order to not be marginalized in the legislature, but Cox et al. (2019) also point to a further explanation for implementing PR; party elites want to increase control over their respective parties, and parties have a 
better chance of obtaining ministerial portfolios in coalitions under PR, given that they do not have single-party majorities. Thus, adopting PR will not only be attractive for maximizing the amount of seats in parliament, but also for having better prospects of obtaining office, and consequently more policy-making power.

The 1919 reform changed the Norwegian electoral system from a two-round single member districts (SMD) to a proportional multi-member districts (PR MMD) electoral system. The first election under the new electoral system was held in 1921, with the first proportionally elected legislature taking seat in 1922. In the period between the reform passing in 1919 and the first election under it in 1921, the parliament also passed the Nomination Act, which formalized the rules of the nomination process. This was not necessarily perceived to increase party leadership control over nominations (Stortingstidende, 1920). Party leaders could, however, "influence the outcome through informal channels [...]" (Cox et al., 2019, 22). In combination with the new electoral system, this is assumed to have boosted party elite's influence over candidate selection for the national elections. In our subsequent analysis, we thus capture the combined effect of the change in electoral reform and the Nomination act.

\section{Methods and Data}

As Carson and Sievert (2015) and Cox et al. (2019) we focus on the behavior of legislators present in the parliament both before and after the reform. In the causal inference language, our effects are ATT, the average treatment effect on the treated. In our case, the treatment is the electoral reform, the treated are those legislators that served in the parliament before the reform, and was re-elected under the new election rules. This is unlikely to be the only effect of the reform. Another effect is the effect of the electoral reform on the composition of the parliament, but in terms of parties and the type of legislators that got elected under the different electoral rules. If we assume that those that only served before the reform were less considerate of the party label than those elected after the reform, then our estimation strategy is likely to underestimate the total 
effect of the reform on the legislative debates.

We utilize a corpus of all individual MP speeches in the Norwegian parliament (Stortinget) from 1910 to 1931. As our argument is that the electoral reform changed the nature of the parliamentary debates when parties become stronger at the expense of individual MPs, we need to identify the evolution of the topics under debate in these speeches. For this task, STM are particular well suited (Roberts et al., 2014). Building on Latent Dirichlet Allocation (LDA) topic models, the structural topic model allows for including covariates that are expected to increase variance between topics (Roberts et al., 2014, 1067). Topic models classify speeches probabilistically into a set of topics on the basis of relevant wordfrequency distribution (Blei and Lafferty, 2009; Blei, 2012). A topic is here defined as a distribution over a fixed vocabulary. For example, a tax topic will contain words related to taxation with a high probability. Each document belong to several topics in varying degrees, making this a multi-membership model. The outcomes of a topic model are the associations of words to topics and the expected proportion of the topic in the corpus of texts. The quantities of key interest, the topic proportions, are inherently unobservable; we only observe the word use and the covariates of the model.

We allow topic-proportions to vary by parliamentary session and include and indicator for whether the speech was given before the passing of the new electoral reform or not. Thus, the speeches held between 1910 through 1921 sessions are coded as before the reform (0), and speeches held from the 1922 through 1930 sessions as after the reform (1). Roberts et al. (2015) develop the case for interpretation of the technique as a highdimensional coarse matching technique where speeches are matched with other speeches based on similarity in relative word frequencies.

Because the inference from the model is conditional on the number of topics selected, we run several models where we let the number of topics vary. Note that the topics and the words associated with the different topics are inferred from the word-use in the speeches, not fixed in advanced. As the number of topics is a way to set the level of abstraction of the topic output, we opt for a relatively low number of topics. This is mainly done in order to not get debate specific topics and keep the level of abstraction 
relatively high in our analyses. Our main model consist of 25 topics $(K=25)$ for which we estimate the STM. ${ }^{1}$

For our post-topic analyses, we use the estimateEffect() function from the stm R-package (Roberts et al., 2017). This function simulates regressions where the topic proportion for a given topic is the dependent variable. We use reform as our treatment variable and control for time by implementing basis spline of the session the speech was held in. Thus, our topics are allowed to appear and disappear over time. For example, the topic denoting structure of the military is more prevalent before and during World War I, than during the 1920s.

We set the number of simulations for each of the relevant topics (see Figure 1) to 500 and extract the mean, 0.05 quantile, and 0.95 quantile as point estimates, lower, and upper confidence interval, respectively.

\section{Descriptive}

Table 1 shows the descriptive differences between our subset and the full data on some key variables. In general, word use, age, and proportion of ministers from towns or cities, and election results remain similar between the two data sets.

Naturally, as shown in Table 2 there are some differences between the two samples in party affiliation. After all, proportional electoral systems tend to produce multiparty systems. However, the three major parties - the Labor Party, Conservatives, and Liberal party - all have about $40 \%$ of the speeches from the full sample in the subsample. Furthermore, as shown by table A1 in the appendix, the period we cover see stable exchanges of government power between the coalition of the Conservatives and Liberal

\footnotetext{
${ }^{1}$ In order to remedy the arbitrariness of choosing the number of topics, we also estimate 5 LDA configurations on both sides of $K=25$, giving us 11 topic models with $K=20 \ldots 30$. We use a combination of the top loading terms - see appendix for top loading terms and translations for our main model - exclusive terms, and most characteristic texts for each topic in order to make sense of what each topic is about in the model with 25 topics. Then, we proceed by searching for the same topic in the other topic models. This is done through looking for high correlations between our models and comparing top loading texts and tokens across the models. By not relying solely on one topic model with a set amount of topics, we ensure that the results from our main analysis is not unduly influenced by the exact number of topics. It suffice here to note that the main results are not unduly driven by the choice of the number of topics. Most other number of topics in the $20-30$ range yield similar results.
} 


\begin{tabular}{lrrrrrr} 
& Words & Age & Town & 1.round & 2.round & PR \\
\hline \hline Min: subset & 21.00 & 23.00 & 0.00 & 0.01 & 0.34 & 0.10 \\
Min: full & 21.00 & 23.00 & 0.00 & 0.00 & 0.34 & 0.09 \\
\hline Mean: subset & 439.95 & 53.32 & 0.33 & 0.51 & 0.54 & 0.36 \\
Mean: full & 430.99 & 52.93 & 0.39 & 0.51 & 0.51 & 0.32 \\
\hline Median: subset & 254.00 & 54.00 & 0.00 & 0.53 & 0.50 & 0.36 \\
Median: full & 251.00 & 53.00 & 0.00 & 0.51 & 0.51 & 0.30 \\
\hline Max: subset & 15032.00 & 77.00 & 1.00 & 0.85 & 0.96 & 0.56 \\
Max: full & 15032.00 & 77.00 & 1.00 & 0.95 & 0.96 & 0.56 \\
\hline \hline
\end{tabular}

Table 1: Descriptive comparison between subset of MPs with seat before and after reform and full data.

Left party and single-party Liberal Party, and that there was no power transition at our treatment point (at the start of 1922 session).

As mentioned, we focus on the subset of representatives occupying parliamentary seats on both side of the reform. This way, we both isolate the effect of the reform on topical content from the effect of the reform on the types of representatives that are elected and safeguard ourselves from obtaining results that are driven by the fact that the reform itself caters for specific types of MPs. To build confidence in the claim that the change occurred with the reform, we conduct two placebo analyses. First we pretend that the reform occurred in 1919, at the start parliamentary term before the reform. This also allows us to investigate to what extent legislators adjusted their behavior strategically. Then, we pretend that the reform came into effect on term later than it actually did, in

\begin{tabular}{llllr}
\hline \hline Party & Party (English) & N & N (all) & \% \\
\hline \hline A & Labor Democrats & 2596 & 3220 & 80.62 \\
DNA & Labor Party & 6045 & 15813 & 38.23 \\
FV & Progressive Liberals & 1184 & 4062 & 29.15 \\
H & Conservatives & 7125 & 17704 & 40.25 \\
NKP & Communist Party & 0 & 722 & 0.00 \\
NSA & Social Dem. Labor Party & 562 & 1199 & 46.87 \\
BP & Farmer's Party & 615 & 5420 & 11.35 \\
Indep. & Independents & 126 & 241 & 52.28 \\
V & Liberal Party & 8864 & 22812 & 38.86 \\
\hline \hline Total & - & 27117 & 71193 & 38.09 \\
\hline \hline
\end{tabular}

Table 2: Number of speeches for parties in the sample containing only MPs with seat before and after reform $(\mathrm{N})$, full data $(\mathrm{N}$ all), and the percentage of speeches in $\mathrm{N}$ of all speeches 
1925. This allows us to investigate the lasting effects of the reform.

\section{Results}

Our topic models uncovered seven topics that will be analyzed by simulating regressions on them: (1) Representative focus, (2) Party politics, (3) Local claims, (4) Building infrastructure, (5) Education, (6) Military, and (7) Primary industry. These topics are summarized in Table 3. A detailed description of the topics can be found in the appendix. We look into whether these topics change according to our expectations about moving from a majoritarian to a proportional representation electoral system.

Here, we present the results from the simulated effects of the reform on the seven topics described in Table 3. We start with a summary of the main substantive findings before going into more of the technical details. We also summarize the results from two placebo reforms. All results are based on comparing the speeches given by MPs that served both before and after the reform. Thus, we are identifying the effect of the reform on MPs subjected to the reform change. The reform did most likely also influence the type of members being elected, but the focus here is on how MPs elected under both system changed their behavior.

The key result is that these MPs changed which topics they emphasized substantively. In particular, party politics became prevalent while representative focus became rare. Moreover, centralized questions such as education gain in prominence, while more local topics such as infrastructure lost prevalence with the reform. While there seem to be

\begin{tabular}{l|l|l|l}
\hline Category & Topic & Expected effect & Summary \\
\hline \multirow{5}{*}{ (a) Substantive } & Local claims & - & Constituency claims to funds \\
& Building infrastructure & $=$ & Expanding infrastructure \\
& Education & + & Facilitating for education systems \\
& Military & - & Structure of the military \\
& Primary industry & $=$ & Produce from primary industry \\
\hline \multirow{2}{*}{ (b) Meta-politics } & Representative focus & - & MP specific politics response \\
& Party focus & + & Party specific politics response \\
\hline \hline
\end{tabular}

Table 3: Topics focused on in the analysis, with expected effect direction and short description. 
more local claims prior to the reform than after the reform, substantial uncertainty is associated with these estimates.

\section{Reform change}

Figure 1 shows the simulated effects of the electoral reform - controlled for basis spline of parliamentary session - on each of the seven topics shown in 3. A general note should be made on the consistently larger confidence intervals in the post-reform period; although there is less data here, there is also generally more variation between the topics, consequently increasing the width of the intervals. This does not seem to be a big issue, as it only makes us more uncertain about the direction of the point estimates within some of the topic regression. Also, as mentioned, these models are based on only the MPs that occupied a seat in parliament both before and after the electoral reform was implemented. This excludes the possibility that the results may be being driven by new types of MPs being elected to parliament after the reform through any other mean than peer effect. Because the composition of parliament, naturally, will change across electoral systems, we also see this peer effect as an effect driven by the reform.

At the top of Figure 1, we see that the representative focus topic - speeches based on addressing and pointing fingers at specific MPs - is more prominent before than after the reform with a topic load of about 8 percent before and 4 percent after. This is in line with our expectation that criticism of specific MPs are more likely when the electoral system gives incentives for individual candidates to promote their agenda rather than on maintaining a strong united party. MPs are more prone to engage in representative focused debates under the candidate-centric than party-centric electoral system. The effect might seem small at first glance. However, because the model is a multi membership model (with 25 possible memberships), a document loading equally on all topics would have a load of $4 \%$. Seeing as most speeches, at least to some degree, load on topics such as parliamentary procedure, the estimated change in expected topic load is quite substantial. 


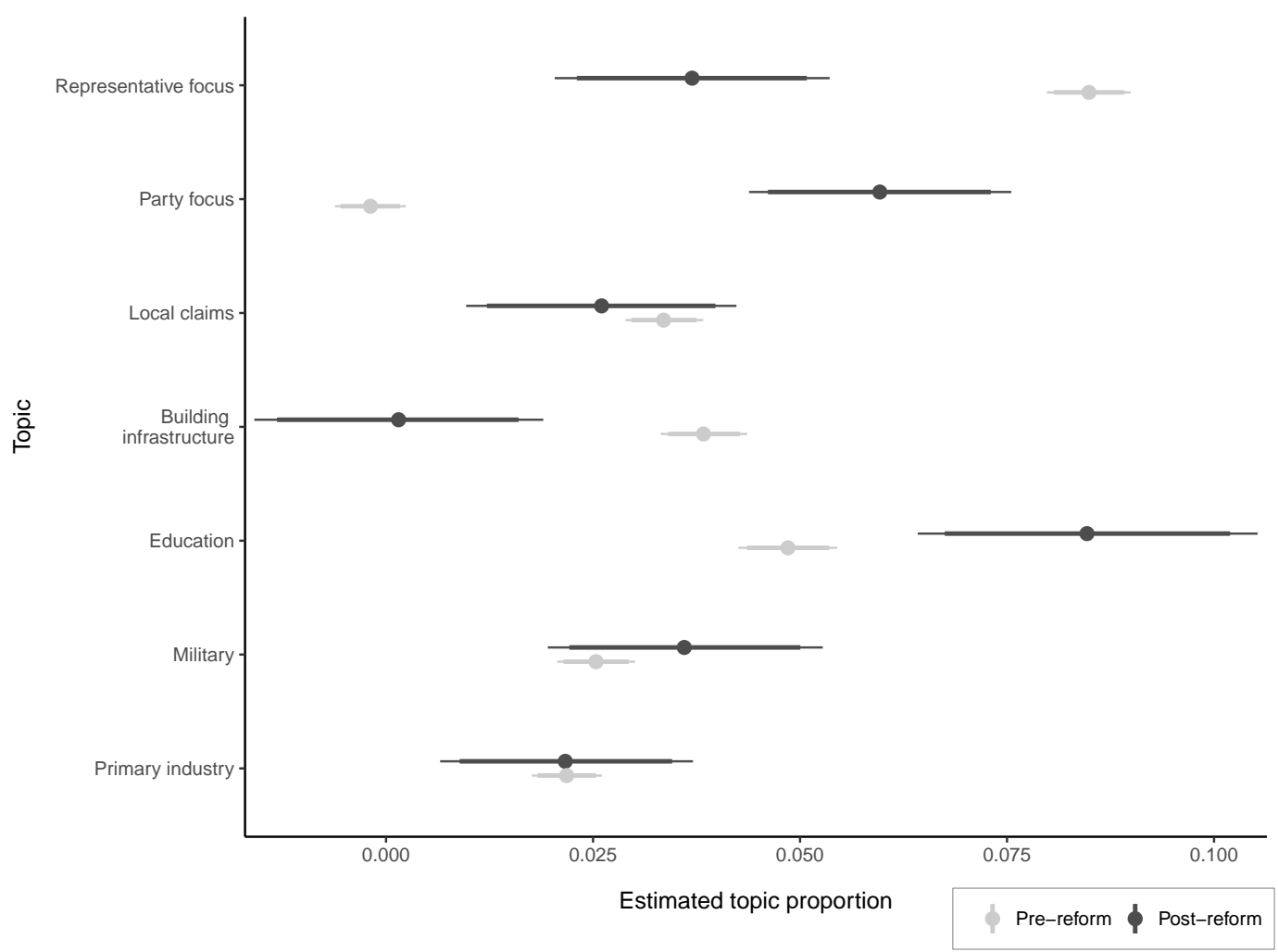

Figure 1: Estimated topic proportions for speeches pre- and post-reform in the topic model with 25 topics. 
As for the reverse topic, we also see the reverse effect. Party politics is more likely post-reform, with a topic proportion of about 0.06 , compared to essentially 0 pre-reform. Hence, we conclude that the reform did indeed increase the party political sentiment in the legislature. In combination with the finding on representative focus, this suggest that party leaders do have more control over the MPs from their own party. After the reform MPs devoted more of their time to party ideology, at the expense of personal agendas.

This latter point would be further strengthened if the local claims topic was more prominent before the electoral reform. As Figure 1 shows, the point estimate goes in the expected direction, but the confidence intervals of pre- and post-reform does cross by a large margin. Consequently, we are hesitant to infer that the reform had an effect on the local claims topic.

Some of the debates in the topic on building infrastructure have constituency specific sentiments; the topic contains high loading debates where MPs argue for building, for example, railway stations in small towns. This seems to also be reflected in Figure 1, which shows that the topic proportion for this topic is significantly higher under the candidate-centric electoral system. Thus, this topic also seems to be directly affected by the electoral reform. MPs with incentives to please their constituency (pre-reform) argue more for building local infrastructure than MPs with incentives to please the party leadership (post-reform). An alternative interpretation of this finding could be that all controversial infrastructure projects were decided prior to the electoral reform came into effect. But this is not the case. The building of railroads was a major undertaking in the whole period from 1890 until 1940.

Similarly, we expected the education topic to either be more prevalent after the reform than before, or have no effect at all, because most of the debates in this topic have a national education policy content, although not exclusively so. Indeed, Figure 1 shows that education has a higher expected topic proportion after the reform than before. Thus, the education topic seems to tap into the same underlying effect of the reform as the infrastructure topic, although with opposite sign. There is more focus on the general aspects of education, wages for teachers, universities, etc., and less on specifics after the 
reform.

As for the military topic, we see a similar but reversed trend to the local claims topic. But this could partly be driven by the socialists versus establishment debates on pacifism and disarmament. Nevertheless, it is not surprising that the military structure is more prevalent during the World War I period than after, especially because of the precarious economic situation in Norway during the 1920s. Moreover, as the effects are highly uncertain, we are hesitant to conclude on this topic.

Finally, Figure 1 shows that the topic of primary industry behaves as expected. Agriculture, fishing, and trade in products from these industries seems to be similarly important on both sides of the reform, with an approximate topic proportion of 0.02 at the point estimate.

\section{Robustness}

To check the robustness of our result to the assumption regarding the number of topics, we here report the results from the main analysis for all topic models with 20 to 30 topics. We identified the relevant topics in each of the models by a combination of high correlations between topic loads from the original model and conducting a qualitative evaluation of the topic content across all models. Figure 2 summarizes the results.

The representative focus topic is much more prominent before than after the reform. As demonstrated in Figure 2, this finding is relatively stable across models, although the confidence interval does cross the pre-reform confidence interval on the models with 23 and 28 topics, and the point estimate is slightly lower on pre-reform on the topic model with 22 topics. However, the effect is stable enough for us to be fairly certain that the electoral reform does have an effect on this topic; MPs are more prone to engage in specific MP criticism under the candidate-centric than party-centric electoral system.

The finding that party politics is more likely post-reform also holds up. Only the topic model with 20 topics has crossing confidence intervals, and all models have the expected point estimate direction. Hence, we are confident that the reform does indeed increase the party political sentiment in the legislature. In combination with the finding 
on representative focus, this finding suggest that party leaders do have more control over the MPs from their own party because MPs devote more of their time to party ideology, rather than personal agendas.

As shown by Figure 2 in the appendix, the effect of the remaining topics are also stable across models.

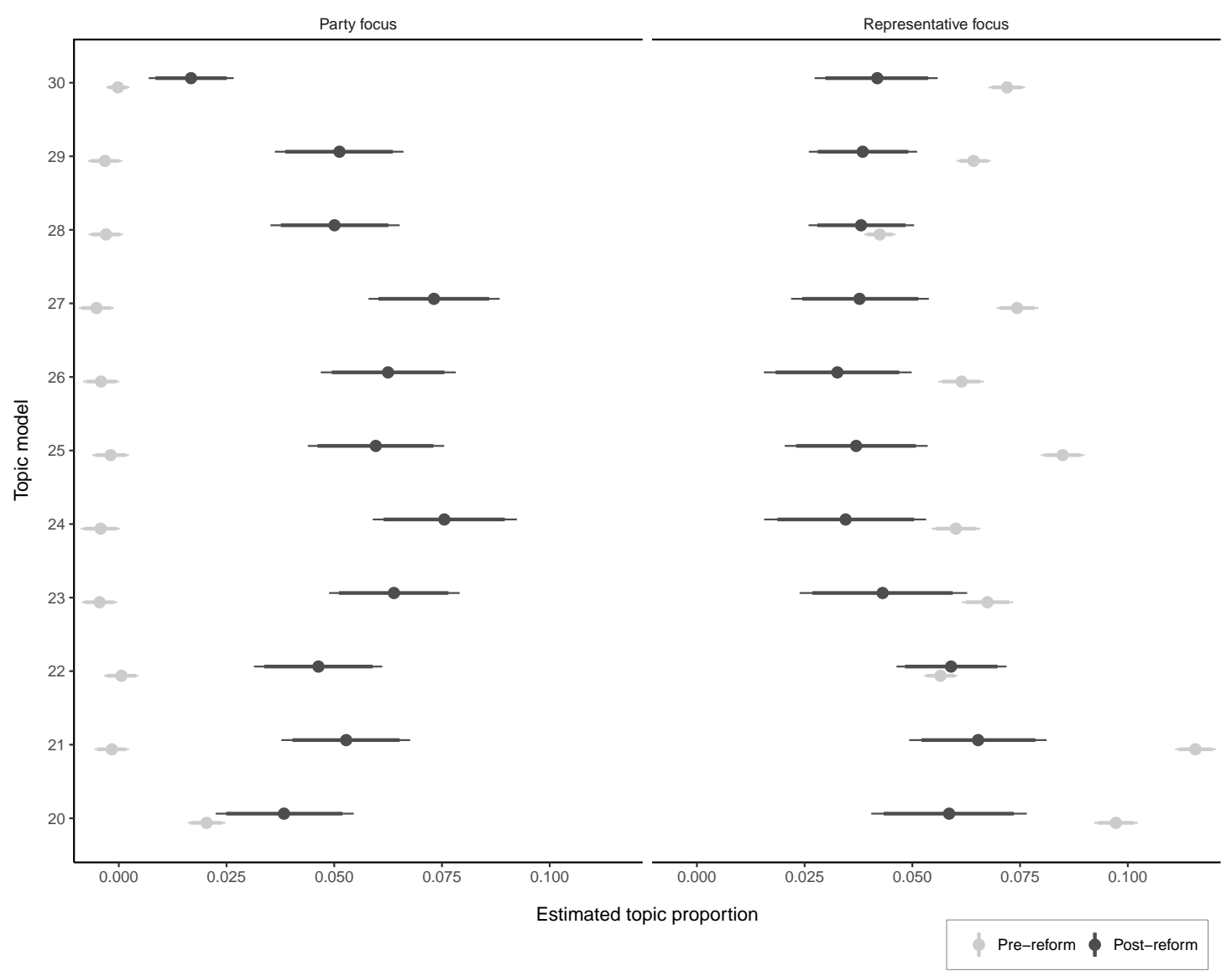

Figure 2: Estimated effect of reform on topic load for given topics.

In total, these results support our claim that the reform had a substantive effect on MPs debating style in the Norwegian Parliament. Prior to the reform, there was a tendency to engage in representative focused debates, as these could be beneficial from an electoral point of view (Fiva and Smith, 2017a). With the reform, the electoral system becomes party-centered; MPs adjust by changing from engaging in debates with individuals in focus to party political and ideological attacks. 


\section{Placebo reforms}

Here, we investigate the effect of two placebo-reforms. First, we pretend that the reform came into effect for the general elections in 1919 rather than 1922. Second, we pretend that the reform happened three years later, with the general election in 1925 .

Placebo 1919 Figure 3 summarized the results from the first placebo-test. The key thing to note is that, compared the to main results, there is very little effect of the placebo-reform on representative focus and party politics. In the case of the former, the point estimates are even in the direction of more representative focus afterwards than before, but we should not read much into this as the confidence intervals show substantial overlap. In terms of party politics, we see that the there point estimates suggest more after the reform than before, but again, the confidence interval overlaps. So while the results form the actual reform showed large reduction in representative focus and a substantive increase in party political speeches, there is very little evidence of a similar effect on the first placebo test. We can thus dismiss the suggestion of reverse causality, which implies that the reform was a result of increased party political tension in parliamentary debates, not a cause of it, as we claim.

In contrast, we do find support for such a gradual trend in the topics of building infrastructure and primary industry, both of which becomes more prevalent after 1919 than before.

Placebo 1925 Figure 4 summarizes the results from the second placebo-test. Here we pretend that the reform only happened in 1925. We thus compare only MPs that served both before and after this election. We see that by now, there are virtually no representative focus any more. Moreover, the difference in the amount of party political speeches are smaller compared to the actual reform. For the other variables, we fail to find any substantive difference pre and post this placebo-reform. In total these results support our claim that the reform had a substantive and lasting effect on MPs debating style in the Norwegian Parliament. Pre-reform, criticism towards specific MPs was more 


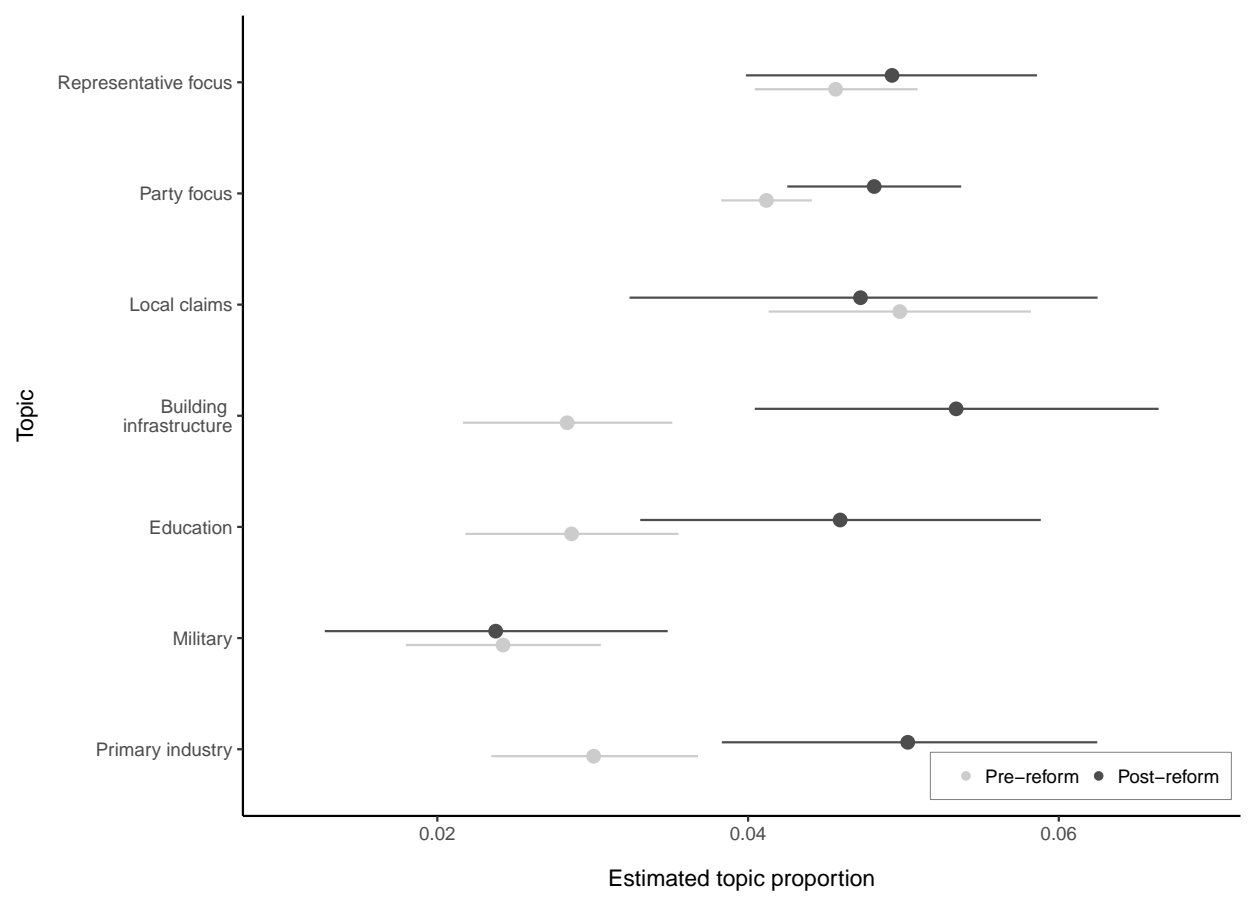

Figure 3: Effect of placebo reform (1919) on selected topics.

present, as this could electorally beneficial (Fiva and Smith, 2017a). With the reform, the electoral system becomes party-centered. MPs adjust, trading personal characteristics for party politics.

\section{Conclusion}

Electoral institutions affect parliamentary behavior. By focusing on parliamentary debates, we demonstrate that individual legislators adapt their speeches to the electoral institutions they inhabit. The Norwegian electoral reform of 1919 changed the electoral system from a candidate-centered system with single member districts to a party-centered closed list proportional system. With speech level data, we are able to scrutinize how the topic-composition of parliamentary debate differ before and after this reform. Our analysis shows substantive change the topic prevalence. With the reform, topics that allow MPs to highlight party differences gained in prevalence while speeches highlighting the (lacking) personal qualities of candidates become less frequent. 


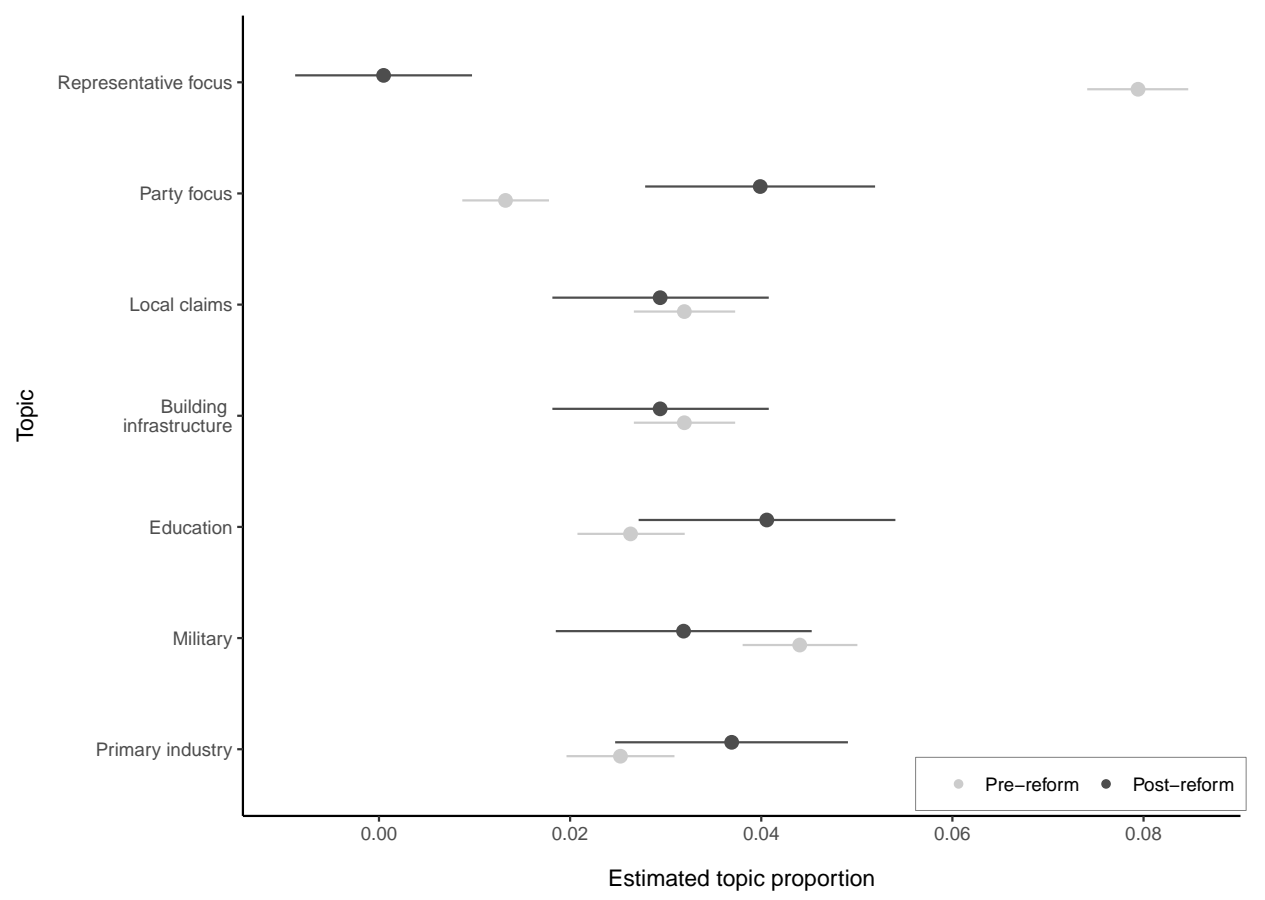

Figure 4: Effect of placebo reform (1925) on selected topics.

Further, this pattern is found both in the form of communication between the MPs and in the substantive content of their speeches. On the one hand, we show that MPs change from engaging in frequent criticism of MPs under the candidate-centered system, to highlighting party ideological differences under the party-centered system. Moreover, we find that the substantive content of speeches are more likely to be constituency focused before the reform than after. For example, the focus on building infrastructure in remote places almost disappeared. The prevalence of constituency budget allocations is reduced after the introduction of PR. Furthermore, topics of broader interest become more frequent after the reform. This latter finding is, however, restricted to such topics as the national education system and the organization of the military. The effect of the latter is, it should be noted, somewhat uncertain.

A core question with regard to the aims of MPs and consequences of parliamentary debates is whether they are deliberative or an position-taking instrument for MPs. Supporting the latter position, Proksch and Slapin (2015, 20-21) assume that parliamentary debates "exist (almost) solely for 'theatrical' purposes, addressed to outside audiences for 
political - as opposed to policy - reasons". It is beyond the scope of this paper to investigate this claim, but MPs do use a significant amount of time on parliamentary debates; newspapers provided substantial coverage of the debates in the time period we cover; and our findings suggest that MPs do adjust their behavior after institutional changes. In a position-taking framework, this could mean that the MPs adjust their strategies for maximizing amount of votes in the upcoming election. On the one hand, MPs can increase their standing in their constituency by crossing the party line - if constituency interests are in conflict with the party of the MP - in a candidate-centric electoral system. On the other hand, sticking to the party label might give the MP higher status in the party, higher position on the ballot, and thus higher probability of getting reelected under the party-centric electoral system.

More broadly, this paper adds to the growing literature on how institutional settings affect behavior among MPs. Our findings support standing theories about politicians' behavior within the field of electoral-legislative relations. The main contribution of our paper is that these tests are done on speech level data. In plenary speeches, the cost of dissenting is seen as lower than that of, for example, voting dissent (Proksch and Slapin, 2015). This could be considered a strong test of party elite control in party-centered systems; MPs do change the way they talk when the electoral system grant more power to the parties. Nevertheless, this does not necessarily suggest that MPs never dissent from the party line on any arena in party-centered systems. One possibility could, for example, be that dissent moves to a level of even lower cost, such as public statements through the media. 


\section{References}

Andre, A., S. Depauw, and M. S. Shugart (2014). Oxford Handbook of Legislative Studies, Chapter The Effect of Electoral Institutions on Legislative Behaviour, pp. $231-249$. Oxford University Press.

Bäck, H. and M. Debus (2016). Political Parties, Parliaments and Legislative Speechmaking. Palgrave.

Blais, A., A. Dobrzzynska, and I. H. Indridason (2004). To adopt or not to adopt proportional representation: The politics of institutional choice. British Journal of Political Science 35(1), $182-190$.

Blei, D. M. (2012). Probabilistic Topic Models. Communications of the ACM 55(4), 77 -84 .

Blei, D. M. and J. D. Lafferty (2009). Topic Models. In A. Srivastava and M. Sahami (Eds.), Text Mining: Classification, Clustering, and Applications. Chapman \& Hall / CRC Data Mining and Knowledge Discovery Series.

Boix, C. (1999). Setting the rules of the game: The choice of electoral systems in advanced democracies'. American Political Science Review 93(3), 609 - 624.

Boix, C. (2010). Electoral markets, party strategies, and proportional representation. American Political Science Review 104(2), 404 - 413.

Calvo, E. (2009). The competitive road to proportional representation: Partisan biases and electoral regime change under increasing party competition. World Politics 61(2), $254-295$.

Carey, J. (2007). Competing principals, political institutions, and party unity in legislative voting. American Journal of Political Science 51(1), 92 - 107.

Carson, J. L. and J. Sievert (2015). Electoral reform and changes in legislative behavior: Adoption of the secret ballot in congressional elections. Legislative Studies Quarteerly 40(1), $83-110$.

Catalinac, A. (2016). From Pork to Policy: The Rise of Programmatic Campaigning in Japanese Elections. The Journal of Politics 78(1), 1-18.

Catalinac, A. (2017). Positioning under Alternative Electoral Systems: Evidence from Japanese Candidate Election Manifestos. American Political Science Review, 1-18.

Coman, E. E. (2012). Legislative behavior in romania: The effect of the 2008 romanian electoral reform. Legislative Studies Quarterly 37(2), 199 - 223.

Cox, G. W., J. H. Fiva, and D. M. Smith (2019). Parties. Legislators, and the Origins of Proportional Representation. Comparative Political Studies 52(1), 102-133.

Depauw, S. and S. Martin (2009). Legislative party discipline and cohesion in comparative perspective. In D. Giannetti and K. Benoit (Eds.), Intra-party politics and Coalition Governments, pp. 103-120. Routledge London. 
Fiva, J. H. and S. Hix (2018). Electoral reform and voter coordination. CESifo Working Paper No. 7289.

Fiva, J. H. and D. M. Smith (2017a). Local candidates and voter mobilization: Evidence from historical two-round elections in Norway. Electoral Studies 45(1), 130 - 140.

Fiva, J. H. and D. M. Smith (2017b). Norwegian parliamentary elections, 1906-2013: representation and turnout across four electoral systems. West European Politics 40(6), $1373-1391$.

Furre, B. (2000). Norsk historie 1914-2000: Industrisamfunnet - frå vokstervisse til framtidstvil. Det Norske Samlaget.

Haffner, V. (1949). Stortinget og statsrådet: 1915-1945. B. 1: Biografier: med tillegg til Tallak Lindstøl: Stortinget og Statsraadet 1814-1914. Aschehoug.

Herzog, A. and K. Benoit (2015). The Most Unkindest Cuts: Speaker Selection and Expressed Government Dissent during Economic Crisis. The Journal of Politics 77(4), $1157-1175$

Hix, S. (2002). Parliamentary behavior with two principals: Preferences, parties, and voting in the european parliament. American Journal of Political Science 46(3), 688 -698 .

Hix, S. (2004). Electoral Institutions and Legislative Behavior: Explaining Voting Defection in the European Parliament. World Politics 56(1), $194-223$.

Høyland, B., S. B. Hobolt, and S. Hix (2017, Mar). Career Ambitions and Legislative Participation: The Moderating Effect of Electoral Institutions. British Journal of Political Science, 1-22.

Imai, K., L. Keele, D. Tingley, and T. Yamamoto (2011). Unpacking the black box of causallity: Learning about causal mechanisms from experimental and observational studies. American Political Science Review 105(4), 765 - 789.

Katz, J. N. and B. R. Sala (1996). Cereerism, committee asignments, and the electoral connection. American Political Science Review 90(1), 21 - 33.

Leemann, L. and I. Mares (2014). The adoption of proportional representation. Journal of Politics $76(2), 461-478$.

Martin, S. (2011). Electoral institutions, the personal vote, and legislative organization. Legislative Studies Quarteerly XXXVI(3), 339 - 361.

McLay, E. and J. Vowles (2007). Redefining Constituency Representation: the Roles of New Zealand MPs Under MMP. Regional and Federal Studies 17(1), 71 - 95.

McLeay, E. and J. Vowles (2007). Redefining constituency represnetation: the roles of new zealand mps under mmp. Regional \& Federal Studies 17(1), 71 - 95.

Obholzer, L. and W. T. Daniel (2016). An online electoral connection? how electoral systems condition representatives' social media use. European Union Politics 17(3), $387-407$. 
Proksch, S.-O. and J. B. Slapin (2012). Insitutional foundations of legislative speech. American Journal of Political Science 56(3), 520 - 537.

Proksch, S.-O. and J. B. Slapin (2015). The Politics of Parliamentary Debate. Cambridge University Press.

Roberts, M. E., B. M. Stewart, and R. Nielsen (2015, July). Matching Methods for High-Dimensional Data with Applications to Text. Working Paper.

Roberts, M. E., B. M. Stewart, and D. Tingley (2017). stm: R Package for Structural Topic Models. R package version 1.2.2.

Roberts, M. E., B. M. Stewart, D. Tingley, C. Lucas, J. Leder Luis, S. K. Gadarian, B. Albertson, and D. G. Rand (2014, Mar). Structural Topic Models for Open-Ended Survey Responses. American Journal of Political Science 58(4), 1064-1082.

Rokkan, S. (1970). Citizens, elections, parties: Approaches to the comparative study of the processes of development. Oslo, Norway: Universitetsforlaget.

Slapin, J. B. and S.-O. Proksch (2014). Words as Data: Content Analysis in Legislative Studies. In The Oxford Handbook of Legislative Studies. Oxford University Press.

Spirling, A. (2016). Democratization and Linguistic Complexity: The Effect of Franchise Extension on Parliamentary Discourse, 1832 - 1915. The Journal of Politics.

Stortingstidende (1920). Love om stortingsvalg og nominasjon. Forhandlinger i Odelstinget.

Wittrock, J. N., S. C. Nemeth, H. Snborn, B. DiSarro, and P. Squire (2008). The impact of the australian ballot on member behavior in the u.s. house of representatives. Political Research Quarterly 61(3), 434 - 444. 


\section{Appendix}

\section{Governments}

\begin{tabular}{llll}
\hline PM & Parties & Start & End \\
\hline Wollert Konow & Conservative, Liberal Left & February 1910 & February 1912 \\
Jens Bratlie & Conservative, Liberal Left & February 1912 & January 1913 \\
Gunnar Knudsen & Liberal & January 1913 & June 1920 \\
Otto Bahr Halvorsen & Conservative, Liberal Left & June 1920 & June 1921 \\
Otto Albert Blehr & Liberal & June 1921 & March 1923 \\
Otto Bahr Halvorsen & Conservative, Liberal Left & March 1923 & May 1923 \\
Abraham Berge & Conservative, Liberal Left & May 1923 & July 1924 \\
Johan Ludwig Mowinckel & Liberal & July 1924 & March 1926 \\
Ivar Lykke & Conservative, Liberal Left & March 1926 & January 1928 \\
Christopher Hornsrud & Labour & January 1928 & February 1928 \\
Johan Ludwig Mowinckel & Liberal & February 1928 & May 1931 \\
Peder Kolstad & Agrarian & May 1931 & March 1932 \\
\hline
\end{tabular}

Table A1: List of Norwegian governments in the period 1910-1932 


\section{Data and preprocessing}

The core of our data - the speeches - consist of over 70000 plenary addresses in the Storting in the period from 1910 trough 1931. These were obtained in raw pdf format from the web-pages of the parliament, ${ }^{2}$ processed with the image editor ImageMagic ${ }^{3}$ and converted to computer readable text with the optical character recognition (OCR) tool Tesseract ${ }^{4}$. Further, we utilize meta-data on politicians from the data described in Fiva and Smith (2017b). These data include county of provenance, gender, age, and a range of other MPs specific variables on all MPs in this time-period.

\section{Optical Character Recognition}

Optical character recognition - or OCR - have made large quantities of previously unattainable historical text available for analysis. ${ }^{5}$ This is also a major benefit for our purpose of exploiting within-case transition from candidate-centered to party-centered electoral systems.

The speeches used in our analyses were first obtained as picture-quality pdfs from the Parliamentary archives. Originally these pdfs were generated by simply scanning each page of the hard-copies of the debates. Hence, the quality of the pdfs vary somewhat as a function of how carefully each page was placed on the scanner as well as the quality of the page scanned. The quality is sufficiently high to be readable for the human eye as well as optical character recognition software. There are, however, some exceptions. For example, the volume covering the 1918 session has some pages of less than optimal quality, which accordingly led to an incomplete text corpus of this session.

After obtaining the scanned documents, we experimented with various settings to enhance the clarity of the printed text. Though this substantively enhances the quality, there are some pages where the results are sub-optimal. We assume that these errors are generated as if random, and we discuss some measures taken to remedy this shortcoming below.

Once the enhanced pictures were produced, we used Tesseract OCR to convert the the pictures into text. Because the formal written language in Norway at the period covered by our analyzes is a Norwegian-Danish hybrid, we tested running OCR on the documents with both Norwegian and Danish language settings. The results for Danish gave a much higher character precision than Norwegian, mostly because the training set for Danish is richer. Thus, all our analysis are based the Danish configuration of the OCR. Finally, we merged the output into one text file per session.

\section{Pre-processing}

After preparing the text with OCR, we used regular expressions to clean up the text and divide it up on a speech-by-speech basis. This was done by using approximate matching on the surname of all MPs, obtained by the data provided by Fiva and Smith (2017b), followed by a colon - a generic indicator of a new speech occurring in the parliamentary records. We also extracted and removed the occurrences of unknown speakers, the

\footnotetext{
${ }^{2}$ https://www.stortinget.no/

${ }^{3}$ https://www . imagemagick.org/

${ }^{4}$ https://github.com/tesseract-ocr/

${ }^{5}$ See for example http://www.hansard-archive.parliament.uk/
} 
parliamentary President speaking, when votes are held, listings of proposals, and the introductory speeches for each session. As mentioned above, the data used in the analyses is a subset of the full data, where speeches held by MPs that sat on both sides of the reform are extracting. We thus leave out speeches by MPs that only occupied a parliamentary seat on only one side of the reform.

We proceeded by using standard pre-processing techniques in order to prepare the texts for STM analyses. This involved a series of operations: First, we removed stopwords from all texts - these are words that do not carry any meaning in content, and are common within most documents, thus not useful for distinguishing between topics. Because there are no available stop-word lists for Danish-Norwegian (the written language in Norway at the time of our study), we hand coded this list, and removed the 100 highest scoring inverse document frequency (idf) words. Second, we remove all speeches that are shorter than 20 words in order to reduce inflation of sparse documents. Third, we remove words that are shorter than 2 characters. This is mainly to remedy of some errors of the OCR process, where extra spaces have been added between characters in the tokens. Fourth, in order to retain some information about word order we construct bigrams and trigrams and thus somewhat relax the bag-of-words assumption - that the word order in a document is irrelevant for its message. We construct a document frequency matrix and remove all documents with less than a total five tokens, bigrams or trigrams. Finally, we also removed all tokens, bigrams or trigrams occurring less than five times in total across all documents.

The resulting matrix includes 63007 unique token unigrams, bigrams, and trigrams over 27117 documents. The reader might notice that the reduction of data is a substantial. However, most of this reduction is due to the removal of speeches from MPs that did not serve both before and after the reform, in addition to minor remarks and introductions by the president. In sum, we opt for only using the data we have the most confidence in having high quality.

\section{Top loading words}

In order to make sense of the content of the topics, we focus on the STM with 25 topics over all speeches in our corpus. To interpret the substantive meaning of each topic we investigated the top 20 frequency-exclusivity (FREX). This score "[...] summarizes words with the harmonic mean of the probability of appearance under a topic and the exclusivity to that topic." (Roberts et al., 2014, 1068); it not only accounts for how high the term loads to the topic, but also the exclusiveness of the term in this topic compared to all other topics. Following our expectations, we focus on the topics that are expected to be affected by the reform. These can be ordered into two categories, as shown by Table 3: (a) substantive and (b) meta-politics topics.

Figure A1 shows the words loading highest on each topic ("Prob"), the most frequent and exclusive words ("Frex"), and the words with the highest Score metric ("Score"). These give an initial impression about the content of topics. However, we can not rely on these exclusively in order to name a topic; reading the top loading texts is vital in order to evaluate the similarity between texts within topics. This is discussed in the next section. 


\begin{tabular}{|c|c|c|c|c|c|c|}
\hline & \multicolumn{2}{|c|}{ Prob } & \multicolumn{2}{|c|}{ Frex } & \multicolumn{2}{|c|}{ Score } \\
\hline 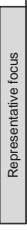 & $\begin{array}{l}\text { æred } \\
\text { repræsentant } \\
\text { regjering } \\
\text { ord } \\
\text { tal } \\
\text { uttal } \\
\text { syn } \\
\text { uttalt } \\
\text { idag } \\
\text { sak } \\
\text { gang } \\
\end{array}$ & $\begin{array}{l}\text { honored } \\
\text { representative } \\
\text { cabinet } \\
\text { word } \\
\text { speaker } \\
\text { comment } \\
\text { view } \\
\text { expressed } \\
\text { today } \\
\text { case } \\
\text { (this) time } \\
\end{array}$ & $\begin{array}{l}\text { æred repræsentant } \\
\text { gunn } \\
\text { sidst æred } \\
\text { hagerup bull } \\
\text { gunn knuds } \\
\text { sidst æred tal } \\
\text { hagerup } \\
\text { knuds } \\
\text { bull } \\
\text { repræsentant } \\
\text { æred tal } \\
\end{array}$ & $\begin{array}{c}\text { honored representative } \\
\text { Gunnar } \\
\text { last honored } \\
\text { Hagerup Bull } \\
\text { Gunnar Knudsen } \\
\text { last honored speaker } \\
\text { Hagerup } \\
\text { Knudsen } \\
\text { Bull } \\
\text { representative } \\
\text { last honored } \\
\end{array}$ & $\begin{array}{c}\text { repræsentant } \\
\text { æred repræsentant } \\
\text { maat } \\
\text { æred } \\
\text { mand } \\
\text { formand } \\
\text { tænk } \\
\text { sidst } \\
\text { staar } \\
\text { sidst æred } \\
\text { faat } \\
\end{array}$ & $\begin{array}{c}\text { representative } \\
\text { honored representative } \\
\text { way } \\
\text { honored } \\
\text { man/one } \\
\text { foreman } \\
\text { think } \\
\text { last } \\
\text { stands } \\
\text { last honored } \\
\text { got } \\
\end{array}$ \\
\hline 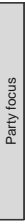 & $\begin{array}{l}\text { regjering } \\
\text { land } \\
\text { ann } \\
\text { folk } \\
\text { parti } \\
\text { syn } \\
\text { idag } \\
\text { sporsmál } \\
\text { gansk } \\
\text { gang } \\
\text { ord } \\
\end{array}$ & $\begin{array}{l}\text { cabinet } \\
\text { country } \\
\text { other } \\
\text { people } \\
\text { party } \\
\text { view } \\
\text { today } \\
\text { question } \\
\text { somewhat } \\
\text { (this) time } \\
\text { word } \\
\end{array}$ & $\begin{array}{l}\text { delegasjon } \\
\text { arbeiderparti } \\
\text { internasjonal } \\
\text { bondeparti } \\
\text { arbeiderregjering } \\
\text { velgern } \\
\text { nasjon forbund } \\
\text { tillit } \\
\text { agitasjon } \\
\text { mads } \\
\text { interpellasjon } \\
\end{array}$ & $\begin{array}{c}\text { delegation } \\
\text { Labor Party } \\
\text { international } \\
\text { Agrarian Party } \\
\text { Labor government } \\
\text { voters } \\
\text { League of Nations } \\
\text { trust } \\
\text { agitasjon } \\
\text { (Alfred Martin) Madsen } \\
\text { interpellation } \\
\end{array}$ & 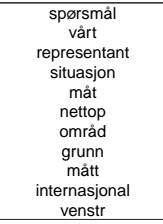 & $\begin{array}{c}\text { question } \\
\text { our } \\
\text { representative } \\
\text { situation } \\
\text { way } \\
\text { just now } \\
\text { area } \\
\text { reason } \\
\text { had (to) } \\
\text { international } \\
\text { left (Liberal Party) }\end{array}$ \\
\hline 墨 & $\begin{array}{l}\text { bevilgning } \\
\text { amt } \\
\text { bidrag } \\
\text { beløp } \\
\text { krav } \\
\text { distrikt } \\
\text { næst } \\
\text { andrag } \\
\text { bevilg } \\
\text { administration } \\
\text { iaar }\end{array}$ & $\begin{array}{l}\text { grant (money) } \\
\text { county (old version) } \\
\text { contribution } \\
\text { price } \\
\text { demands } \\
\text { district } \\
\text { next } \\
\text { application } \\
\text { grant } \\
\text { administration } \\
\text { this year }\end{array}$ & $\begin{array}{c}\text { amt } \\
\text { bergenhus } \\
\text { amtsting } \\
\text { havnedirektør } \\
\text { nordland amt } \\
\text { tromsø amt } \\
\text { andrag } \\
\text { bergenhus amt } \\
\text { trondhjem amt } \\
\text { søndr bergenhus } \\
\text { romsdal amt } \\
\end{array}$ & $\begin{array}{c}\text { county (old version) } \\
\text { Bergenhus } \\
\text { county assembly } \\
\text { port director } \\
\text { Nordland county } \\
\text { Tromsø county } \\
\text { application } \\
\text { Bergenhus county } \\
\text { Trondhjem county } \\
\text { Sondre Bergenhus } \\
\text { Romstdal county } \\
\end{array}$ & $\begin{array}{c}\text { amt } \\
\text { bevilgning } \\
\text { anlæg } \\
\text { amtsting } \\
\text { administration } \\
\text { finmark } \\
\text { bidrag } \\
\text { beløp } \\
\text { tromsø amt } \\
\text { iaar } \\
\text { andrag } \\
\end{array}$ & $\begin{array}{l}\text { county (old version) } \\
\text { grant (money) } \\
\text { facility } \\
\text { county assembly } \\
\text { administration } \\
\text { Finmark } \\
\text { contribution } \\
\text { price } \\
\text { Tromsø county } \\
\text { this year } \\
\text { application }\end{array}$ \\
\hline$\frac{\mathrm{g}}{\mathrm{s}}$ & $\begin{array}{c}\text { ban } \\
\text { jernban } \\
\text { plan } \\
\text { bygg } \\
\text { hovedstyr } \\
\text { jernbanekomite } \\
\text { bygning } \\
\text { kristiani } \\
\text { station } \\
\text { anlæg } \\
\text { drift } \\
\end{array}$ & $\begin{array}{l}\text { railway } \\
\text { railway } \\
\text { plan } \\
\text { building } \\
\text { executive board } \\
\text { railway committee } \\
\text { building } \\
\text { Kristiania } \\
\text { station } \\
\text { facility } \\
\text { operation }\end{array}$ & $\begin{array}{c}\text { jernbanekomite } \\
\text { station } \\
\text { ombygning } \\
\text { lokomotiv } \\
\text { hovedban } \\
\text { rull materiel } \\
\text { jernbaneanlægg } \\
\text { jernbanekomit } \\
\text { jernbanekomite formand } \\
\text { teknisk konsulent } \\
\text { østbanestation }\end{array}$ & $\begin{array}{l}\text { railway commilttee } \\
\text { station } \\
\text { reconstruction } \\
\text { lokomitive } \\
\text { main railway } \\
\text { railway vehicles } \\
\text { railway installation } \\
\text { railway committee } \\
\text { railway committee chair } \\
\text { technical consultant } \\
\text { east railway station }\end{array}$ & $\begin{array}{l}\text { jernbanekomite } \\
\text { jernban } \\
\text { hovedstyr } \\
\text { ban } \\
\text { anlæg } \\
\text { station } \\
\text { ombygning } \\
\text { dovreban } \\
\text { jernbanern } \\
\text { rull materiel } \\
\text { jernbaneplan }\end{array}$ & $\begin{array}{l}\text { railway commilttee } \\
\text { railway } \\
\text { executive board } \\
\text { railway } \\
\text { facility } \\
\text { station } \\
\text { reconstruction } \\
\text { Dorrebanen } \\
\text { railways } \\
\text { railway vehicles } \\
\text { railway plan }\end{array}$ \\
\hline 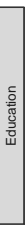 & $\begin{array}{l}\text { skol } \\
\text { stilling } \\
\text { lon } \\
\text { lønning } \\
\text { klass } \\
\text { hoier } \\
\text { pension } \\
\text { elev } \\
\text { folkeskol } \\
\text { funktionær } \\
\text { aar } \\
\end{array}$ & $\begin{array}{c}\text { school } \\
\text { position } \\
\text { salary } \\
\text { salary } \\
\text { class } \\
\text { higher } \\
\text { pension } \\
\text { student } \\
\text { elementary school } \\
\text { official/functionary } \\
\text { years course } \\
\end{array}$ & $\begin{array}{c}\text { Iærer } \\
\text { middelskol } \\
\text { lærerskol } \\
\text { alderstillæg } \\
\text { gagekomite } \\
\text { landpostbud } \\
\text { aar middelskol } \\
\text { postmestr } \\
\text { pension } \\
\text { postaapnern } \\
\text { skol } \\
\end{array}$ & $\begin{array}{c}\text { teacher } \\
\text { middle school } \\
\text { teachers college } \\
\text { age increment } \\
\text { salary committee } \\
\text { countryside postman } \\
\text { years middde school } \\
\text { chief of police } \\
\text { pension } \\
\text { post opener } \\
\text { school } \\
\end{array}$ & $\begin{array}{c}\text { skol } \\
\text { folkeskol } \\
\text { middelskol } \\
\text { elev } \\
\text { løn } \\
\text { pension } \\
\text { ærorer } \\
\text { funktionær } \\
\text { alderstillæg } \\
\text { Iærerskol } \\
\text { tjenestemænd } \\
\end{array}$ & $\begin{array}{c}\text { school } \\
\text { elementary school } \\
\text { middle school } \\
\text { student } \\
\text { salary } \\
\text { pension } \\
\text { teacher } \\
\text { official/functionary } \\
\text { age increment } \\
\text { teachers college } \\
\text { civil servant } \\
\end{array}$ \\
\hline 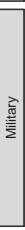 & $\begin{array}{c}\text { militær } \\
\text { hær } \\
\text { marin } \\
\text { militærkomite } \\
\text { forsvar } \\
\text { forsv } \\
\text { sig } \\
\text { ovels } \\
\text { forsvarsdepartement } \\
\text { dag } \\
\text { officer } \\
\end{array}$ & $\begin{array}{c}\text { military } \\
\text { army } \\
\text { marine } \\
\text { military committee } \\
\text { defense } \\
\text { defense } \\
\text { say/self } \\
\text { exercise } \\
\text { Department of Defense } \\
\text { day } \\
\text { officer } \\
\end{array}$ & $\begin{array}{c}\text { officer } \\
\text { vernepligt } \\
\text { æred forsvarsminist } \\
\text { forsvarskommission } \\
\text { underofficer } \\
\text { officerern } \\
\text { ovelsern } \\
\text { arme } \\
\text { hærbudgett } \\
\text { brigad } \\
\text { oberst } \\
\end{array}$ & $\begin{array}{c}\text { officer } \\
\text { conscription } \\
\text { honored Minister of Defense } \\
\text { defense commission } \\
\text { subordinate officer } \\
\text { officers } \\
\text { exercise } \\
\text { army } \\
\text { military budget } \\
\text { brigade } \\
\text { colonel }\end{array}$ & $\begin{array}{c}\text { militær } \\
\text { militærkomite } \\
\text { officer } \\
\text { marin } \\
\text { ovels } \\
\text { hær } \\
\text { eged niss } \\
\text { forsvarsminister } \\
\text { eged } \\
\text { forsvarsminist } \\
\text { vernepligt } \\
\end{array}$ & $\begin{array}{c}\text { military } \\
\text { military committee } \\
\text { officer } \\
\text { marine } \\
\text { exercise } \\
\text { army } \\
\text { Egede Nissen } \\
\text { Minister of Defense } \\
\text { Egede } \\
\text { Minister of Defense } \\
\text { conscription }\end{array}$ \\
\hline & $\begin{array}{l}\text { jord } \\
\text { land } \\
\text { pris } \\
\text { korn } \\
\text { jordbruk } \\
\text { bruk } \\
\text { statsminister } \\
\text { monopol } \\
\text { mel } \\
\text { kjop } \\
\text { norsk } \\
\end{array}$ & $\begin{array}{l}\text { land/dirt } \\
\text { country } \\
\text { price } \\
\text { grain } \\
\text { farming } \\
\text { use } \\
\text { Prime Minister } \\
\text { monopoly } \\
\text { flour } \\
\text { buy } \\
\text { Norwegian }\end{array}$ & $\begin{array}{c}\text { gaardbrukern } \\
\text { smaabrukern } \\
\text { sammalt } \\
\text { smaabruker } \\
\text { sammalt mel } \\
\text { opdyrkning } \\
\text { prestegaard } \\
\text { udyrk } \\
\text { korn } \\
\text { jord } \\
\text { nydyrkning } \\
\end{array}$ & $\begin{array}{c}\text { farmer } \\
\text { owners of a small farm } \\
\text { ground whole } \\
\text { owner of a small farm } \\
\text { wholemeal flour } \\
\text { cultivation } \\
\text { rectory } \\
\text { uncultivated } \\
\text { grain } \\
\text { land/dirt } \\
\text { land reclamation } \\
\end{array}$ & $\begin{array}{c}\text { jord } \\
\text { jordbruk } \\
\text { dyrk } \\
\text { mindstepris } \\
\text { sælg } \\
\text { korn } \\
\text { kjot } \\
\text { monopol } \\
\text { smaabrukern } \\
\text { gaardbrukern } \\
\text { mel } \\
\end{array}$ & $\begin{array}{c}\text { land/dirt } \\
\text { farming } \\
\text { cultivate } \\
\text { minimal price } \\
\text { sell } \\
\text { grain } \\
\text { meat } \\
\text { monopoly } \\
\text { owners of a small farm } \\
\text { farmer } \\
\text { flour } \\
\end{array}$ \\
\hline & & English & 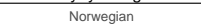 & & Norwegian & English \\
\hline
\end{tabular}

Figure A1: Translation of top words in selected topics for topic model with 25 topics over different top load and exclusivity measures. 


\section{Topic structure}

Of the 7 topics we investigate, the first topic is a local claims topic, which mainly contains detailed budget grants and allocations to solve very specific constituency problems based on MPs from that constituency detailing why this is important. For example, one of the top loading texts from 1914, is a speech by MP Hagbarth Lund showing how happy he was for a grant to Borlevaag within his own constituency (Østfinnmarken), because this was "[...] an old request, that finally has been solved". Or when MP Nils M. Kulstad from the district Nordre Helgeland was persistently arguing for increasing grants in order to build a telephone installation within his constituency:

I want to request from the administration, that it, in its budget for the next year, include a post for grants to a telephone installation in Glein-KobberdalHov-Tomma-Handnes $\varnothing$-Longset $[\ldots]^{6}$

Because this is the epitome of candidate-centric speeches, we expect this topic to be more prevalent in the period before the transition to a more party-centric electoral system.

The next topic contains the debates on building infrastructure, and particularly railways - which was a huge national project during the period covered here. The topic is characterized by the tokens "station", "reconstruction" (ombygning), "locomotive" (lokomotiv), "trunk line" (hovedbane), and so on. The topic also load highly on terms related to sea infrastructure for both produce and passengers. Reading the most characteristic speeches in this topic, we see that this is a product of trying to consider maximal infrastructure coverage over the country; building train routes from port to port was not prioritized over covering inland areas. The top loading debates are characterized by discussions over technical specifications (for example, how wide the rails on different stretches should be) and disagreement over how to prioritize this. Because some of the speeches loading high in this topic includes strong local sentiments for building and improving infrastructure to and through small towns and districts, we could expect this topic to be more prominent before the electoral reform.

We also identify a topic containing debates on how to structure the education system and compensation for teachers. This topic is also quite stable across all topic models, except for the model with 25 topics. Here, we note that the topic also includes tokens such as pension (pension) and salaries (gage). This topic is, nevertheless, not initially expected to be affected by the electoral reform, as building a school system is a slow and important task for a fairly new state. However, this topic could be expected to be more prevalent post-reform, because the topic is more about general policies, such as teacher wages, curriculum for the lower levels of education, and language variants (bokmål versus nynorsk), rather than constituency oriented debates on education (hypothetically, we could expect debates on discontinuation of local schools with few students to be an example of constituency based education speech).

Further, we identify a topic that contain debates on the grants to and structure of the military. Typically, this topic is characterized by discussions on specific military posts (officer, oberst, etc), conscription (verneplikt), military training (øvelser, rekruttskole), and the budget of the military (hœrbudgett). For example, MP Ole Monsen Mjelde

\footnotetext{
6 "Translated by the authors from: Jeg vil henstille til administrationen, at den $i$ sit budgetforelag for naste aar optar forslag om bevilgning til telefonanlægget Glein-Kobberdal-Hov-Tomma-Handnesø-Longset $[\ldots] "$
} 
argued that "[...] we have, after the passed legislation on ordering of the military, a surplus of officers that can be used as platoon leaders [...]"7 in a debate on the military budget of 1910 . We do not expect this topic to be affected by the reform.

The primary industry topic emphasises on agriculture, fish, and forestry. Farmers (gaardbruker, smaabruker), cultivation (nydrykning, opdyrkning, udyrk), and products from farming (potet, korn, sammalt mel) are the most exclusive high frequency tokens for this topic. One of the top loading speeches held by MP Gunder Anton Jahren in 1917. It serves as a good example of the main content of this topic. During a debate on production efficiency and pricing of farming products, he proclaimed that "The assembly often encourage farmers to do whatever can be done to produce as much as possible, and that is sensible $[\ldots]$ But it is inconsistent to proclaim that the [...] the price on Norwegian corn should not be reduced." 8 In the models with fewer topics, this topic also includes different terms on tolls and pricing produce, which makes sense as the period under scrutiny here is characterized by a troubled Norwegian economy and strong dependence on international trade - especially on fish (Furre, 2000, 21). Given the precarious economic situation, this topic is not expected to be affected by the reform itself.

Next, we identify a topic characterized by focus on individual representatives. This topic is especially interesting because of its non-party oriented speech structure. These sentiments should be more prevalent before the reform - when incentives are more oriented towards individuals - than after the reform - when incentives are more party-centered. With regard to the exclusive terms, this topic includes phrases such as "honored representative" (arede reprasentant), vocal and prominent MPs during the period (Gunnar Knudsen and Edvard Hagerup Bull, both parliamentary leaders for the Liberal and Conservative party, respectively), and tokens such as "sincere" (oprigt) and "express" (uttrykke). Investigating the most characteristic speeches for this topic in detail, we noticed that it seldom had any substantive political content, but rather attacks on MPs that had spoken previously in the debate. For example, the top loading text in this topic is a speech from Wollert Konow in 1911, where he counter criticism from a fellow MP by stating that: "[...] There are contradictions here, that I described as a slimy way of making an argument, something I am sticking with." 9 Similarly, the second top loading text was held by Johan Casteberg 1916. Countering a previous speaker, he stated that "The representative has shown, throughout the day, that he can be wrong, mishear, and misinterpret." 10 budget Moreover, in the 1912 session, MP Finn Blakstad (Conservative Party) noted that:

When there is doubt in whether one has read something correctly by oneself, I would really put distrust in the last honored speaker's ability to read correctly

\footnotetext{
${ }^{7}$ Translated by the authors from: [...] vi efter den vedtagne harordning har en mangde overtallige officerer, og disse overtallige kan $i$ overgangstiden anvendes som pelotonførere

${ }^{8}$ Translated by the authors from: Man kommer jo her gang efter gang med opfordringer til gaardbrukerne om at gjøre, hvad gjøres kan, for at producere mest mulig, og det er jo meget rimelig [...] Men da synes jeg, det er litt inkonsekvent at sige, at der ikke skal ydes bidrag til reduktion av prisen for dem som vil kjøpe av norskavlet korn [...].

${ }^{9}$ Translated by the authors from: Det er motsatningen her, som jeg betegnet som en slimet maate at argumentere paa, og det fastholder jeg.

${ }^{10}$ Translated by the authors from: At reprasentanten kan ta feil og høre feil og misforstaa, har han vist tidligere idag.
} 
by himself. ${ }^{11}$

in a discussion about a proposition on a new reform of the railway system.

These quotes illustrate how MPs critiqued previous speakers during substantive debates. As mentioned, we expect this topic to be more prevalent during the candidatecentric than party-centric electoral system.

Finally, the party focus topic contains speeches with party political sentiment. We note terms such as Labor Party (arbeiderparti) and Farmer's Party (bondeparti) denote party politics. However, in the combination of exclusive and frequent terms, there is also some foreign policy aspects here, such as League of Nations (nasjonenes forbund), international (internasjonal), delegation (delegasjon). The reason is that a lot of the top loading texts in the topic are party polarized debates over foreign affairs combined with high level of party ideology. For example, a good illustration is a speech by MP Arne Magnussen in 1927, under a debate on the League of Nations. Magnussen, answering a previous speaker, stated that: "The social democratic party has had just as strong opposition to the Conservatives as the Labor Party has today [...]", ${ }^{12}$ clearly fronting his party label. Furthermore, the top texts of this topic give a general impression that this is mainly about party policies and ideology. Interestingly, some aspects of this topic is similar to the representative focused topic, but with more attacks against opposing parties or the government, rather than specific MPs. We expect this topic to be more prevalent after the electoral reform, where party leaders are expected to have more power, and, the party brand to carry more importance for vote-seeking MPs.

Additionally, some notes are necessary on the residual topics, which broadly fits into categories of parliamentary procedure, budget discussions, speeches held in Nynorsk (the second official written Norwegian language), noise, and unstable topics. Obviously, noise from the OCR process is not interesting for the task at hand, although it encouraging that it is filtered out as its own topic. Further, parliamentary procedure speeches are less interesting with regard to the effect of reform, as these are speeches for structuring the daily work of the parliament - something we are not expecting to be any more or less necessary after the reform. Similarly, budget term topics, including terms such as money (penger), bank, tax (skatt), and more, are not likely to change in itself after the reform.

\footnotetext{
${ }^{11}$ Translated by the authors from: "Naar der er drat $i$ tvil, om man har last rigtig indenad, vil jeg virkelig dra den sidste arede talers evne til at lase indenad i tvil."

${ }^{12}$ Translated by the authors from: "Det socialdemokratiske parti har sttt $i$ et likes sterkt kampforhold til hire som Det norske arbeiderparti gjr idag"
} 


\section{Robustness analyses}

In this section, we present a series of robustness checks for our main findings. First we highlight the main results from our analysis in tabular format. Second, we show the results from models with varying amounts of topics $(K=20 . .30)$. Third, we highlight the stability of our findings for the representative focus topic on the full sample. We also note that the party politics topic is not stable in this configuration.

\section{Main analysis}

Table A2 shows the raw numbers underlying figure 1 in table format. As discussed above, the representative focus and party focus topics have the expected direction. At the mean, we can expect a $4.8 \%$ decrease in emphasis on the representative focus topic when going from pre- to post-reform. The party focus topic shows the reverse effect; at the mean, we can expect a representative to utilize this topic $6.2 \%$ more after the reform than before the reform.

As for the remaining topics, the local claims, military, and primary industry topics have overlapping 95\% confidence intervals across the reform. However, the infrastructure was less prevalent after the reform than before (3.7\% decrease at the mean). And, the education topic was more emphasized after the reform than before $(3.6 \%$ increased at the mean).

\begin{tabular}{lc}
\hline Topic & Difference \\
\hline Representative focus & $-0.048(-0.070,-0.026)$ \\
Party focus & $0.062(0.041,0.082)$ \\
Local claims & $-0.007(-0.029,0.013)$ \\
Building infrastructure & $-0.037(-0.060,-0.014)$ \\
Education & $0.036(0.010,0.063)$ \\
Military & $0.011(-0.011,0.032)$ \\
Primary industry & $0.000(-0.020,0.019)$ \\
\hline
\end{tabular}

Table A2: Estimated effects from main analysis $(\mathrm{K}=25) .95 \%$ confidence intervals are shown in parentheses. Negative numbers indicate that the topic was less pronounced after the reform; positive numbers indicate that the topic was more pronounced after the reform. 


\section{All models effects}

Figure A2 shows the estimated effects over all topics described above, but also over topic models with varying amounts of topics, ranging from 20 to 30. Shortly, as discussed above, the representative and party focus topics have relatively stable and expected direction on their effects over the different topic models.

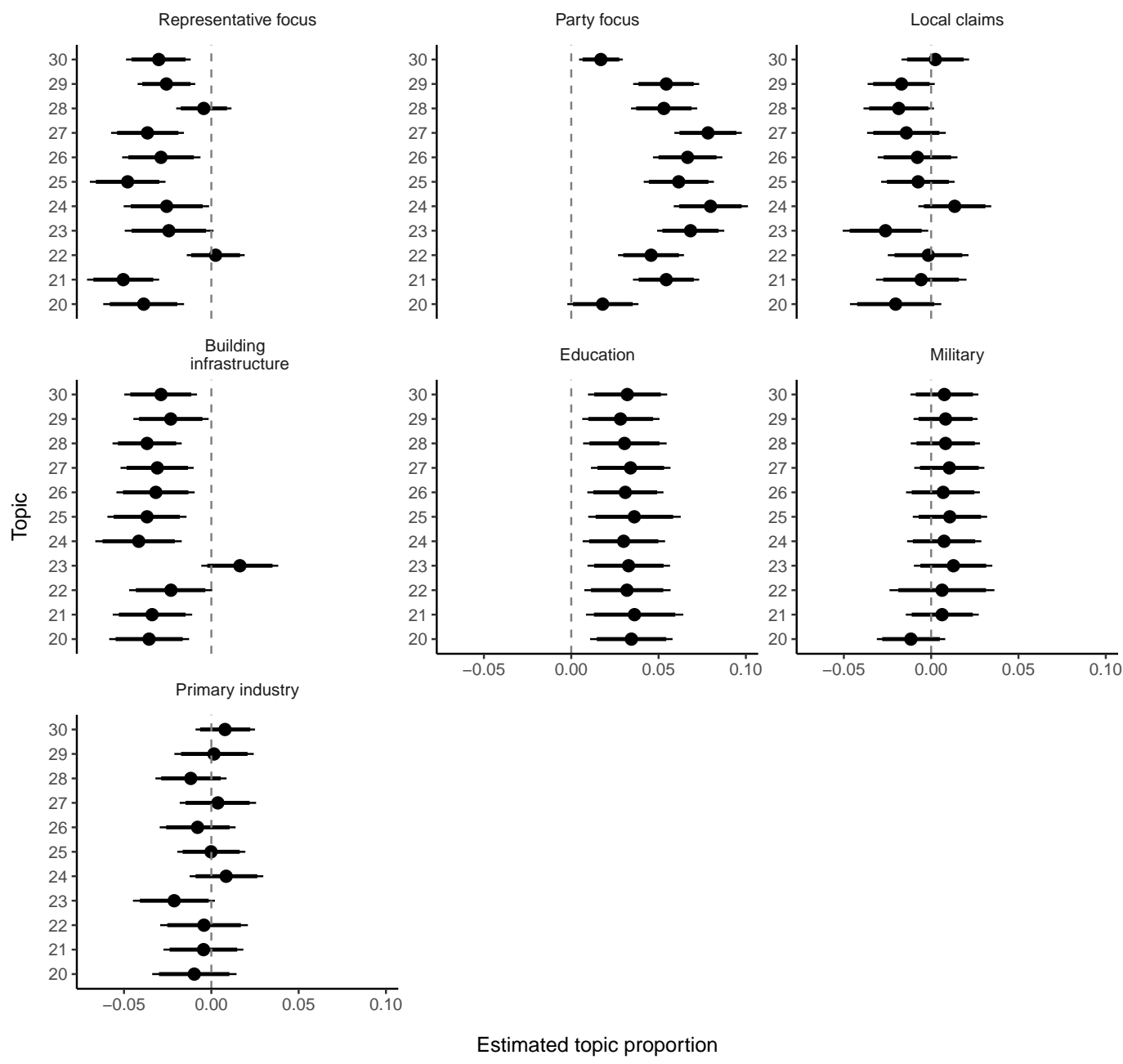

Figure A2: Estimate difference in all models. Negative estimates indicate higher topic proportion before the reform, and positive estimates higher topic proportions after the reform. The horizontal lines show $95 \%$ and $90 \%$ confidence intervals. 


\section{Full data effects}

In this section, we discuss our main finding in light of a full sample model. As is evident from the right panel of Figure A3, the representative focus topic behaves very similar to the main analysis here; this topic was more emphasized before the reform than after. However, the party focus topic shows some instability in this configuration, varying in both direction and magnitude over the different topic models.

This does give reason for some concern over the results for this topic from our main analysis. But, the concerns are limited to whether the original results can be generalized to the MPs occupying parliamentary seats under one, and only one, of the electoral systems. Given the full data analysis, we conclude that they can not. Our overarching argument, that if an MP in a candidate centered system will change the content of their speeches under a party centered system, should still stand. Furthermore, the party focus topic is more unstable in the full sample analysis; it also concerns other aspects of debate than party focus.

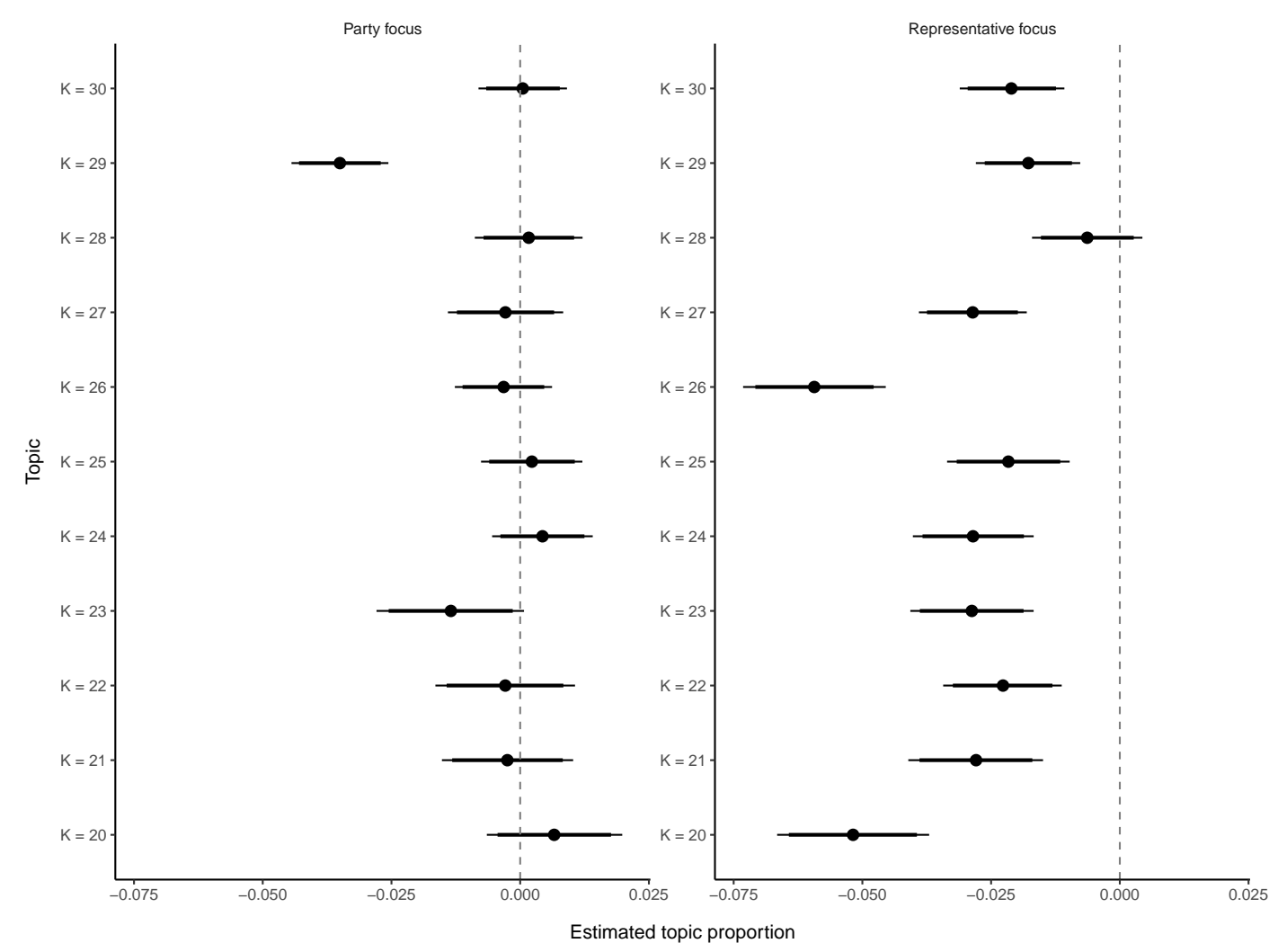

Figure A3: Estimated difference for full sample models over the representative and party focus. 